Article

\title{
New Logistics Paradigms in Poland
}

\author{
Elżbieta Gołembska
}

Department Finance and Banking, WSB University of Poznańul, Powstańców Wielkopolskich 5, 61-895 Poznań, Poland; elzbieta.golembska@wsb.poznan.pl

Received: 5 June 2019; Accepted: 15 July 2019; Published: 25 July 2019

\begin{abstract}
This article presents the results of theoretical and empirical studies on the search for new logistics development paradigms needed to meet the challenges of the twenty-first century global economy. The author reviews the major factors determining the effectiveness of international processes and operations, including logistics success potentials in supply chains. Furthermore, the article proposes methods for measuring logistics performance, specifically the logit model and the model of fuzzy logic, which could be used to assess whether a firm's planned investments in logistics infrastructure will end in success or failure. The article also evaluates the impact of logistics on the development of international trade in the practice of Polish firms. The studies cover a period before Poland's accession to the European Union (EU) (2000 to 2004), and after the accession, from 2005 to 2016, and are supplemented with a forecast for logistics development in Polish firms until 2020.
\end{abstract}

Keywords: logistics paradigms; international business; logit model; strategic alliances; the practice of logistics in Poland

\section{Introduction}

The phenomenon of a growing importance of logistics in international business stimulates the formulation of new, direction setting paradigms for logistics development in contemporary economies.

The purpose of this article is to present-on the basis of theoretical and empirical studies-the new logistics paradigms that have a significant impact on the competitiveness of Polish enterprises in the context of twenty-first century international business. The article consists of three contextually interrelated parts.

The importance of the search for new paradigms stems directly from the interdisciplinary character of international business. Logistics has been included among performance determining factors of international business operations, along with finance, technological innovation, and demand. A particular importance has been attributed to the business success potential of an enterprise in a supply chain, with the sources of new paradigms, including the growth of diversified capital flows, development of unique strategic alliances between transport and logistics firms, and a broadening scope of logistics competences.

The second part of the article reviews the findings of empirical studies conducted in Polish enterprises for the years 2000 to 2016, and provides a projection of logistics development in the studied firms until 2020. The study refers to three stages/periods-first: Prior to Poland's accession to the European Union (EU), i.e., the period 2000 to 2004; second: The period 2005 to 2016 following Poland's accession to the EU; third: A forecast of logistics development until 2020. The researchers used proprietary personal interview questionnaires, and the expert-opinion method involving the participation of logistics specialists in the practice of strategic management in multinational corporations.

The third part of the article proposes new methods of measuring logistics performance in international business, with a particular fous on the logit model. A real-life enterprise is chosen to 
evaluate the chances of success or failure of planned direct investments. The calculations include survey results from 146 firms investing in logistics infrastructure; the Statistica 10PL software package was used. Another measuring method described is a fuzzy logic model, which is used to eliminate from a supply chain those firms that do not satisfy the criteria of competitiveness in international business.

\section{Sources of New Logistics Paradigms in International Business}

The strong growth of logistics, especially in its international dimension, could be attributed primarily to the interdisciplinary nature of international business. It is worth mentioning that international business is defined as a sub-discipline of economic science, where its purpose is to study economic operations at an international level [1]. Recognizing the interdisciplinary character of international logistics, we also need to identify factors determining the efficiency and rationality of international business operations. In this context, it is important to note the fact that, along with finance, technology, and innovation, the effectiveness of international operations is also determined by price, demand, and inventory. Consequently, all these factors equally determine the performance and rationality of logistics operations, which today are written into corporate strategies.

Moreover, strategic management involves the management of multiple firms making up the links in an international supply chain. In this context, in international business a particular role is attributed to business logistics potentials. According to, the business success potentials in the logistics area determine if a company can achieve, but also sustain a competitive advantage of firms networked in a supply chain [2]. The origin of important relations between logistics and international business can be traced to the concept of world-class logistics, a notion that emerged from theoretical and empirical studies conducted by the Global Logistics Research Team at Michigan State University (1995) [3]. The work of that research team was based on an assumption that by gaining so-called "logistics excellence" a firm will not only be able to make an impact in international business, but may also achieve the level of world-class logistics, and thus satisfy the needs and expectations of its clients by gaining a competitive advantage in the marketplace. Incidentally, as a starting point to world-class logistics, Goldsby and Stank [4] recognized the need to identify the major logistics factors of success of an enterprise. In their research, the authors of the world-class logistics concept focused primarily on high-quality production and distribution planning systems, including logistics cost planning.

The Global Logistics Research Group [3] studied 111 firms and evaluated the effect of logistics success factors on business competitive advantage. The studies were conducted in North America, Europe, and in the Pacific Basin, and the survey results were evaluated on a five-level Likert scale, where the score of 1 represented the least significant influence, and the score of 5 the most significant influence (Figure 1).

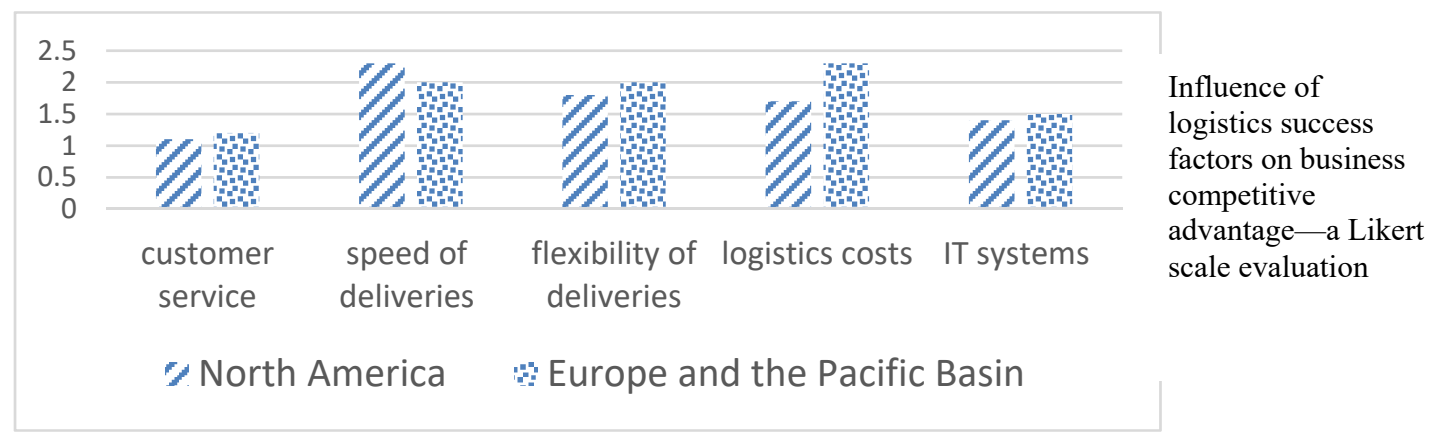

Figure 1. The influence of specific logistics success factors on business competitive advantage in North America, Europe, and in the Pacific Basin.

As highlighted in the study, the most significant business success factors in logistics area include customer service, information systems and technology, and logistics costs. The findings were particularly applicable to North America, where at the time of the study (the turn of the twentieth 
century) logistics had developed at the fastest rate. In the twenty-first century, international logistics became to be defined as planning, implementation, and control of the flow of goods and services between countries. David and Stewart [5] were among the first who highlighted the role of cultural, economic, and financial differences between nations in international logistics. Hence, in logistics management it is worthwhile to use not only the functions of international trade, but also elements of international marketing, intercultural communication, and international finance, elements that will assist companies in achieving a competitive advantage in the marketplace.

A continuous broadening of the scope of international logistics not only accelerates internationalization of enterprises, but also stimulates the global flow of factors of production. International supply chains provide a foundation for such flows. The role of logistics in the global flow of factors of production was first highlighted in 2014 [6]. Deemed as particularly significant were:

- Capital flows, including direct foreign investments in new distribution channels

- Technical knowledge flows, including the application of new technology and patents

- Labor flows, including specialists with logistics competences

A question arises: Why should we regard the growing flows of capital, knowledge, and people as a primary source of new logistics paradigms in international business? The answer to this question is a hypothesis, whereby owing to these economic flows, strong and stable relations are formed between firms in a supply chain, and a broadening scope of such relations leads to the establishment of new market channels, both in Europe and worldwide. In Poland, $60 \%$ of EU funding obtained by small and medium sized enterprises is used to finance construction of storage facilities and modernization of transport fleets. A valuable manifestation of the growing importance of economic flows between countries and world regions comes in the form of direct foreign investments. These are particularly important for Poland and countries of Central and Eastern Europe.

The second important source of new logistics paradigms in international business is the ever-growing preponderance of strategic alliances formed by logistics, transport, and shipping firms in newly-created market channels [7]. The point of such alliances is that allied firms achieve a competitive advantage in a region or in their respective industries, while carrying out their business activities independently.

A new trend has recently been observed, whereby strategic alliances have been formed not only between transport and logistics firms, but also between logistics operators and providers of specific logistics services. The first Polish studies in this area conducted in the years 2013 to 2017 [8] found that the principle aims of strategic alliances were:

- Improving the competitive position of a company within a specific industry or market segment

- Increasing the scope of services offered

- $\quad$ Gaining access to a distribution network

- Improving company resource efficiency

It was also found that better logistics resources and capabilities boost business activities and increase logistics success potentials of a firm in a supply chain.

And finally, the third source of new logistics paradigms in international business relates to a systematic, comprehensive improvement and multiplication of logistics competences. It is generally recognized that such competences enhance the ability to use logistics resources effectively in the long term. Logistics competences are the capabilities on which rely the most important corporate strategic goals: Financial and those pertaining to the flow of goods, services, and information in new market channels. A gradual transition from supply channel orientation to process orientation is now apparent. This transition is presumably due to the fact that in the case of process orientation logistics, processes are treated as subsystems of the value-added creation system. Consequently, efforts are directed not only towards achieving a competitive advantage, but also towards efficiency improvement of those processes. 
The choice of the discussed sources of logistics paradigms is subjective and derives from empirical studies in the area of international logistics.

\section{Logistics in the Practice of International Business in Poland-Research Findings}

This part of the article considers the question whether the practice of Polish firms reflects the new logistics paradigms. As suggested in the previous section, these paradigms include increased capital flows, unique strategic alliances, and optimal logistics competences.

To begin with, the growing importance of logistics in international business has raised logistics share in the gross world product to the present 13.8\% (13.0\% in Europe). Moreover, the world Bank predicts that until 2020 this share will increase by 3.2\%. [9]. This has informed the need to conduct a study on "the living tissue" of Polish companies with foreign capital and international reach. It was considered useful to divide the study into three periods: 2000 to 2004, i.e., before Poland's accession to the EU, the years 2005, 2009, 2012, and until 2016, i.e., after Poland's joining the EU, and projected logistics development from the present until 2020 (The studies were conducted within the framework of a GRANT obtained by the Department of International Logistics at Poznań University of Economics, and their findings have been published in numerous articles and monographs, such as: E. Gołembska, Logistics in the global economy, C.H. Beck, Warsaw 2009: E. Gołembska, PWN Publishers, Warsaw 2014; E. Gołembska, Z. Bentyn, J. Majchrzak-Lepczyj, PWN Publishers, Warsaw 2015.).

The choice of the Wielkopolska region for the study was justified by its geographical location, in particular the presence of domestic and European transit routes, and accessibility to transport and logistics infrastructures. It is worth noting that in 2013 the province of Wielkopolska was ranked fourth among voivodships of Poland by the number of firms with foreign capital participation; an $83 \%$ increase compared with the year 1999 [10].

Foreign capital in the Polish firms originated from 63 countries, mainly EU members, with Germany (26\%) and the Netherlands (24.5\%) being the biggest contributors, closely followed by France, Belgium, and the United Kingdom. Among other major contributors were Denmark, Sweden, and Spain. The scope of the study covered mainly logistics infrastructures, including transport, warehousing, information technology, investments, exports, imports, and also logistics organization, management methods, and cost of logistics. The empirical study was limited exclusively to firms with foreign capital, and the survey methods used were:

- The questionnaire,

- Face-to-face interviews,

- Telephone interviews,

- Expert-opinion method.

Empirical studies require a multidimensional appraisal of logistics operations. The measurement was conducted with the use of:

- Simple metrics: Likert scale, trend extrapolation

- Complex metrics: Panel method (SPSS statistical program), Pearson's method.

Thus, in the period 2000 to 2004, i.e., before Poland's accession to the EU, a survey panel of 145 firms was established, representing all 31 counties of the Wielkopolska province. The firms were, on average, $25 \%$ foreign-owned and operated in such industries as trade, services, transport, food processing, and manufacturing [11]. The investigated period was characterized not only by a strong influx of foreign capital, but also a rapid development of intellectual capital, technical thought, innovation, and modern methods of logistics management. Furthermore, in those years international corporations or their branches placed their logistics specialists in firms located in the Wielkopolska region, who-in addition to their day-to-day duties-trained Polish logistics managers. That in itself was an acknowledgement that the host firms presented value to the investors. It is noteworthy that already in the period shortly before Poland's accession to the EU, logistics infrastructure investments 
were channeled as follows: $42 \%$ of the spending was used to finance the construction and modernization of storage facilities, $38 \%$ was used for expansion and modernization of transport fleets, and $20 \%$ was allocated to the purchase of state-of the-art information technology. The improved availability of logistics infrastructures in the Wielkopolska region determined the directions of exports and imports: $81 \%$ of exports were directed to EU countries, and also Russia and Ukraine, while imports came mainly from the USA, Australia, China, and Brazil.

The studies conducted in 2005 of small and medium-sized enterprises, otherwise known as "global by birth", found that those firms adopted a holistic approach to logistics, whereby manufacturing and logistics processes were integrated in a coordinated strategic management. This particular study covered 101 firms representing all 61 counties of the Wielkopolska province [11]. Importantly, the holistic approach to company management ensured transparency and observance of financial rules in investment planning, such as continuity of investment and risk planning. Consequently, in the studied sector of SMEs, $60 \%$ of equity capital and EU funds obtained by firms was spent on logistics infrastructure, including the construction and modernization of storage facilities, expansion and modernization of transport fleets, and the purchase of the latest management supporting information technology [12].

In 2009 the panel of 2004 was repeated, but this time 98 of the 145 firms participated fully in the survey, while the remaining companies were only interviewed by telephone. Compared with the period before Poland's accession to the EU (2000 to 2004), by 2009 logistics activities in the surveyed firms had developed significantly, with a greater foreign capital engagement, bigger volumes of exports and imports, and a coordinated management of logistics operation being the key trends of that development. As could be expected, after Poland's accession to the EU, the influx of foreign capital into the Wielkopolska region firms accelerated (Figure 2).

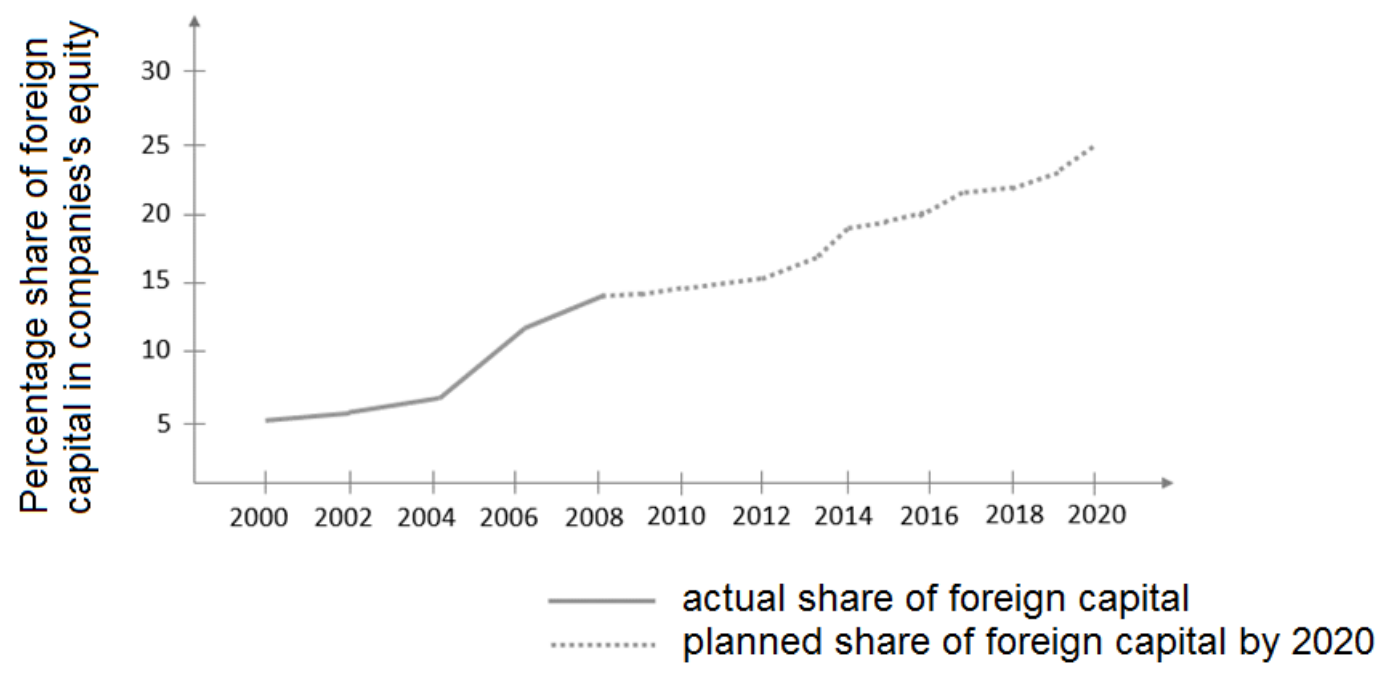

Figure 2. The percentage share of foreign capital in firms' equity, actual for the period 2000 to 2008, and planned by 2020. (Source: Own study).

The period 2004 to 2009 was characterized by a diversification of export and import directions and a steady growth of foreign trade, especially exports (Figure 3).

The bigger role of logistics in companies' operations is connected with changes in the forms and methods of logistics management, which consisted mainly of the transition from logistics operation management to strategic coordination of the entire supply chain. That was a key feature of logistics development in Polish firms. The changes also applied to the forms of supply chains, from simple to enhanced, including agile and predatory (Figure 4). The studies in the Wielkopolska region revealed that agile supply chains were created mainly in pharmaceutical and food processing industries. 


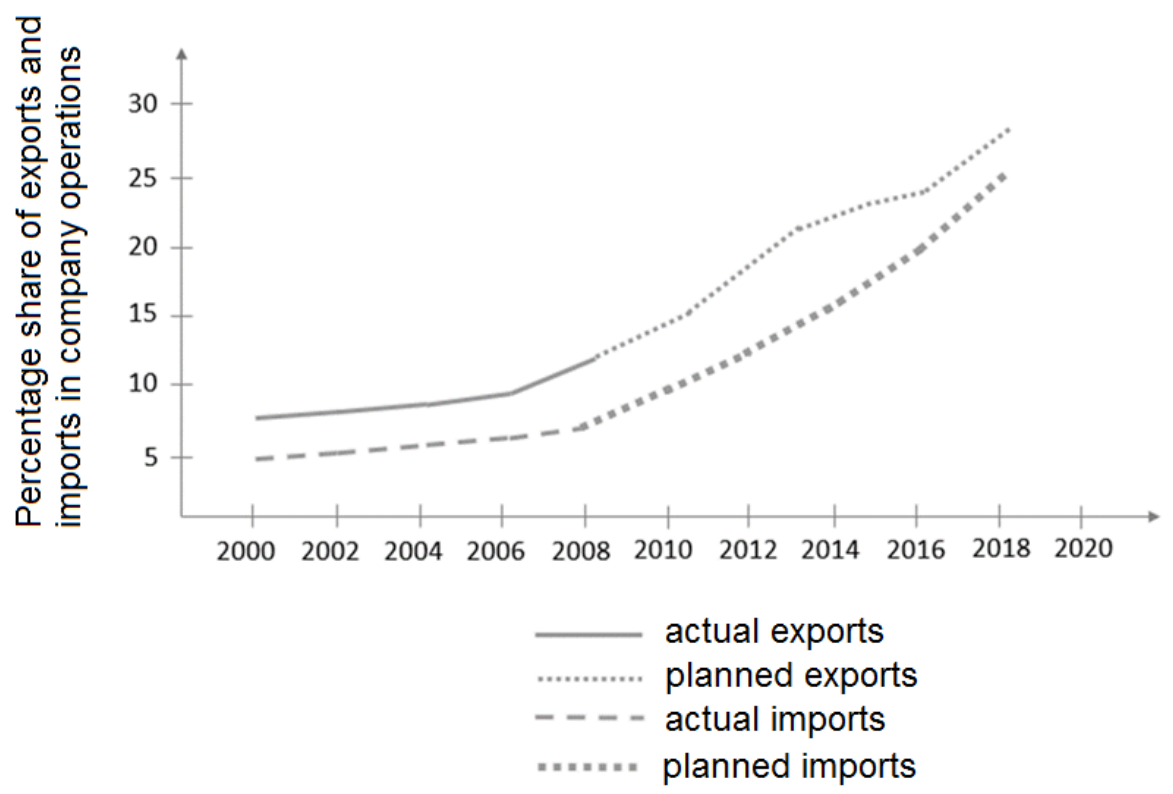

Figure 3. The percentage share of exports and imports in companies' trading in the period 2000 to 2008, with a projection until 2020 (expressed in \%) (Source: Own study).

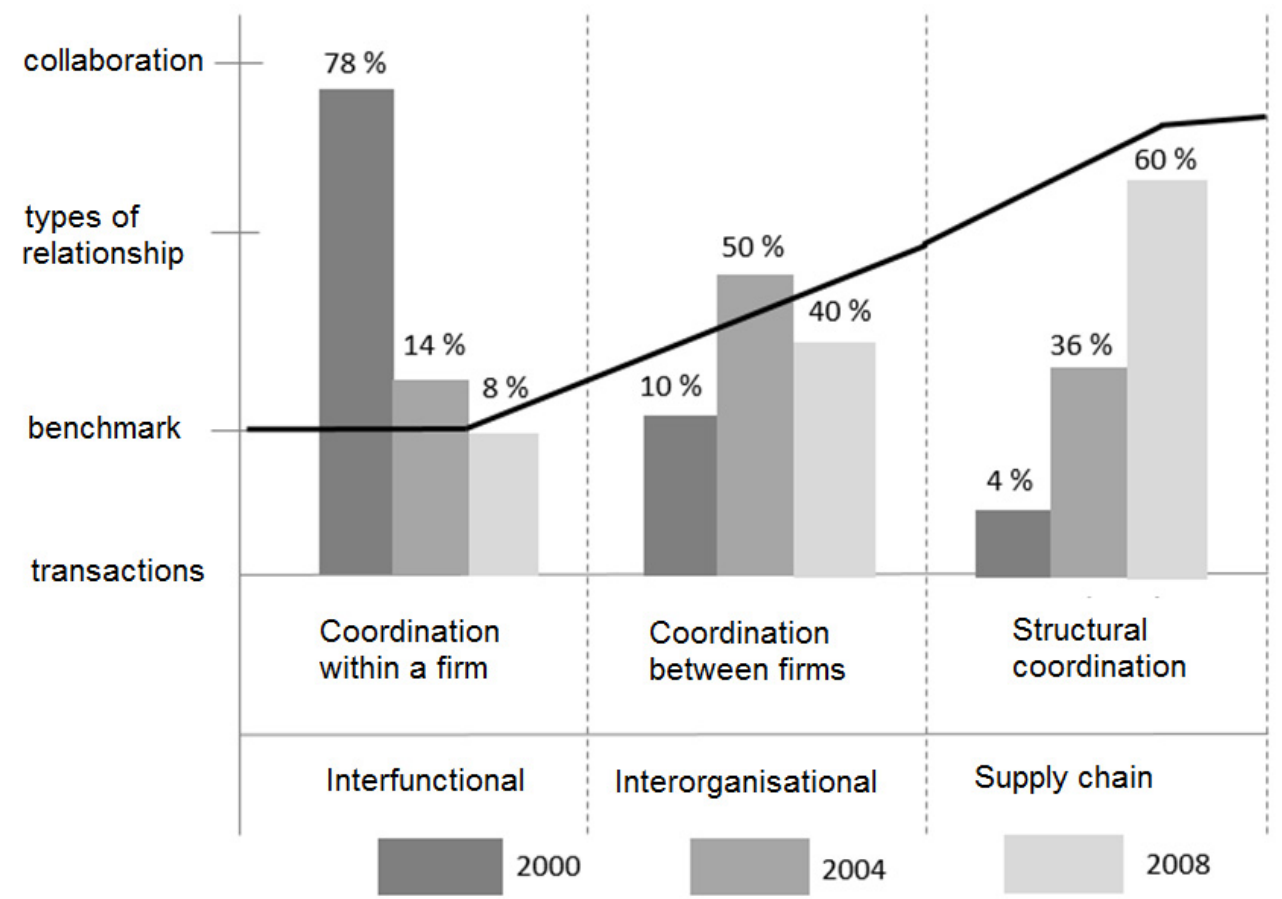

Figure 4. From interfunctional coordination to the supply chain (Source: Own study).

The third stage of the study covered the period 2012 to 2014, with a projection of logistics development until 2020. In this part of the research the method of expert opinion was used. From among international corporations affiliated in the Partner Club of Poznan University of Economics, a group of ten firms representing the Wielkopolska region were selected. A direct interview questionnaire was prepared, and using face-to-face contact with experienced business practitioners, a diagnosis of logistics activities in the firms was made, together with expert opinion on the prospects of future development of logistics in specific companies until 2020. A proprietary variety of the expert opinion method [13] with an analytical scheme for the research, enabled an in-depth assessment of logistics 
operations execution, complemented with insightful and comprehensive opinions by the experts. The logistics function in international corporations was evaluated in the following three aspects:

(1) Reorganization of the management and company structure

(2) Changes in the amount and structure of investments

(3) Growth of volume, and change in the structure of exports and imports

Re.1. In the period 2012 to 2014, 69\% of investigated firms reorganized the structure of their business. The key change consisted of appointing the company's vice-president as head of the logistics department, similarly to the practice observed in foreign firms. With regard to strategic management, where logistics became a strategy in its own right, long term contracts were reduced to a duration of 3 years, and joint investments between the closest partners in the supply chain became normalized. It is envisaged that by 2020 , logistics in all major companies will be managed centrally by the company's vice-president.

Re.2. Reorganizations of the management structure resulted in positive changes in the amount and structure of company investments. It must be added that the share of foreign capital in the equity of all firms investigated in the survey ranged from $39.7 \%$ to $60.1 \%$. In the period 2012 to 2014 , investment in logistics infrastructures constituted $39.2 \%$ of total investments, and are projected to reach $60.2 \%$ by 2020 . It is worth noting that the investigated firms have established their own logistics centers, and increasingly outsource transport services. This ensures a 24-h logistics processing and has reduced logistics costs to the level ranging from $12.8 \%$ to $14.2 \%$.

Re.3. Along with the rationalization of company management in the period 2012 to 2014, this period witnessed a steady growth of trade, and changes in the structure of exports and imports (Table 1).

Table 1. Directions of exports and imports in the period 2012 to 2014 in the ten investigated firms representing the Wielkopolska region.

\begin{tabular}{|c|c|c|}
\hline & EXPORT & IMPORT \\
\hline $\begin{array}{c}\text { EU } \\
\text { countries }\end{array}$ & $\begin{array}{l}\text { Germany, France, United Kingdom, Italy, } \\
\text { Lithuania, Latvia, Estonia, Romania, Bulgaria, } \\
\text { Greece, Austria, Ireland, Czech Republic, } \\
\text { Slovakia, Spain, Portugal, Sweden, Hungary, } \\
\text { Denmark, the Netherlands }\end{array}$ & $\begin{array}{l}\text { Germany, Czech Republic, Spain, } \\
\text { Italy, France, Romania, the } \\
\text { Netherlands, Austria, Belgium, } \\
\text { Slovakia, United Kingdom }\end{array}$ \\
\hline $\begin{array}{c}\text { Other } \\
\text { countries }\end{array}$ & $\begin{array}{l}\text { Belarus, Russia, Ukraine, Kazakhstan, } \\
\text { Kyrgyzstan, Uzbekistan, Mongolia, Serbia, Israel, } \\
\text { Iran, Morocco, Libya, Turkey, Algeria, Slovenia, } \\
\text { RSA, Canada, North and South America }\end{array}$ & China, Turkey, Brazil, Ukraine \\
\hline
\end{tabular}

The findings of empirical studies were used to test the validity of the other two logistics paradigms in international business, as characterized earlier. The first one refers to strategic alliances (Strategic alliances are formed between tactical or potential competitors in order to coordinate companies' competences and resources.) between logistics, transport, and shipping companies, including alliances in new distribution channels, and their role in the development of logistics in the twenty-first century. The studies were conducted for the years 2013 to 2016 on 28 such firms across all regions of the country. The researchers used a proprietary questionnaire containing 27 questions, and analyzed the responses using such tools as the Likert scale, the SPSS statistical software, and data bases of ad hoc surveys by Data group Consulting, a market research agency in Warsaw.

Survey participants were selected purposefully using the following criteria:

- Companies of international reach,

- Logistics, transport, and shipping firms,

- Companies with annual net sales exceeding 50 million Polish zlotys. 
Firstly, it is noteworthy that between 2002 to 2015 the number of logistics, transport, and shipping firms increased steadily, as illustrated by the following diagram (Figure 5):

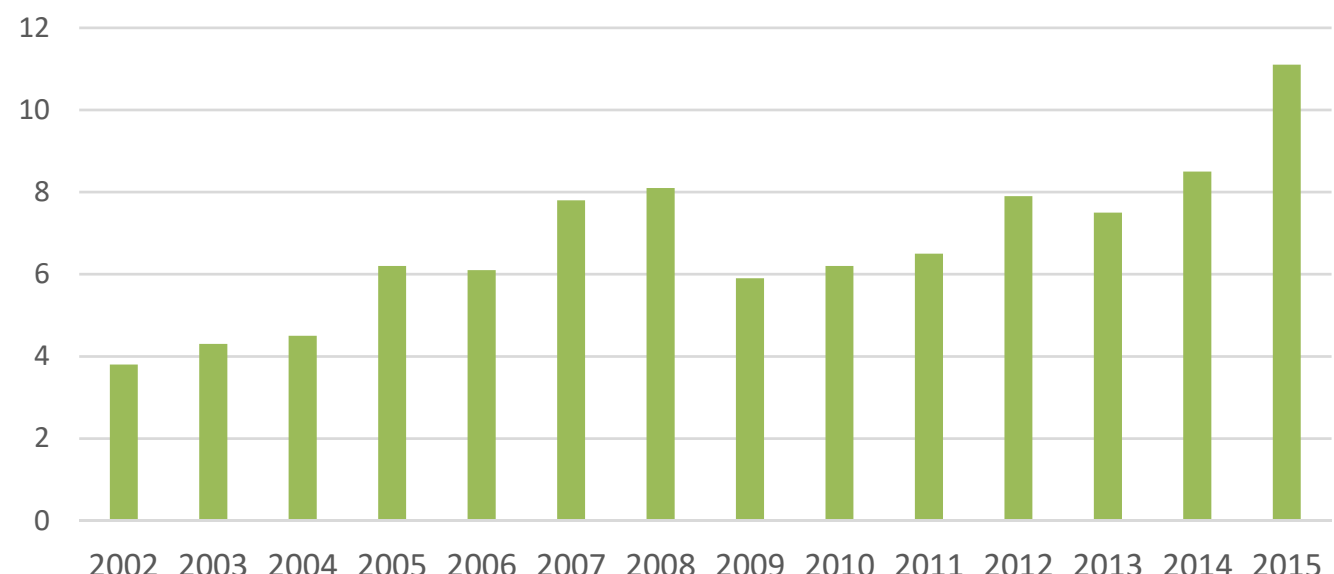

Figure 5. The number of logistics, transport, and shipping companies in Poland operating both in the domestic and international markets. (Source: P. Szuster, 2015, Logistics Operator of the Year 2015, Eurologistics No 91, page 21.).

It is very likely, therefore, that the bigger number of such firms facilitates the formation of strategic alliances, especially with the view to share and coordinate material and human resources, and logistics competences.

Furthermore, as highlighted in the statistical data (Main Office of Statistics), the financial standing, and therefore economic performance of logistics (Figure 6), transport, and shipping (including warehousing) firms, systematically improved:

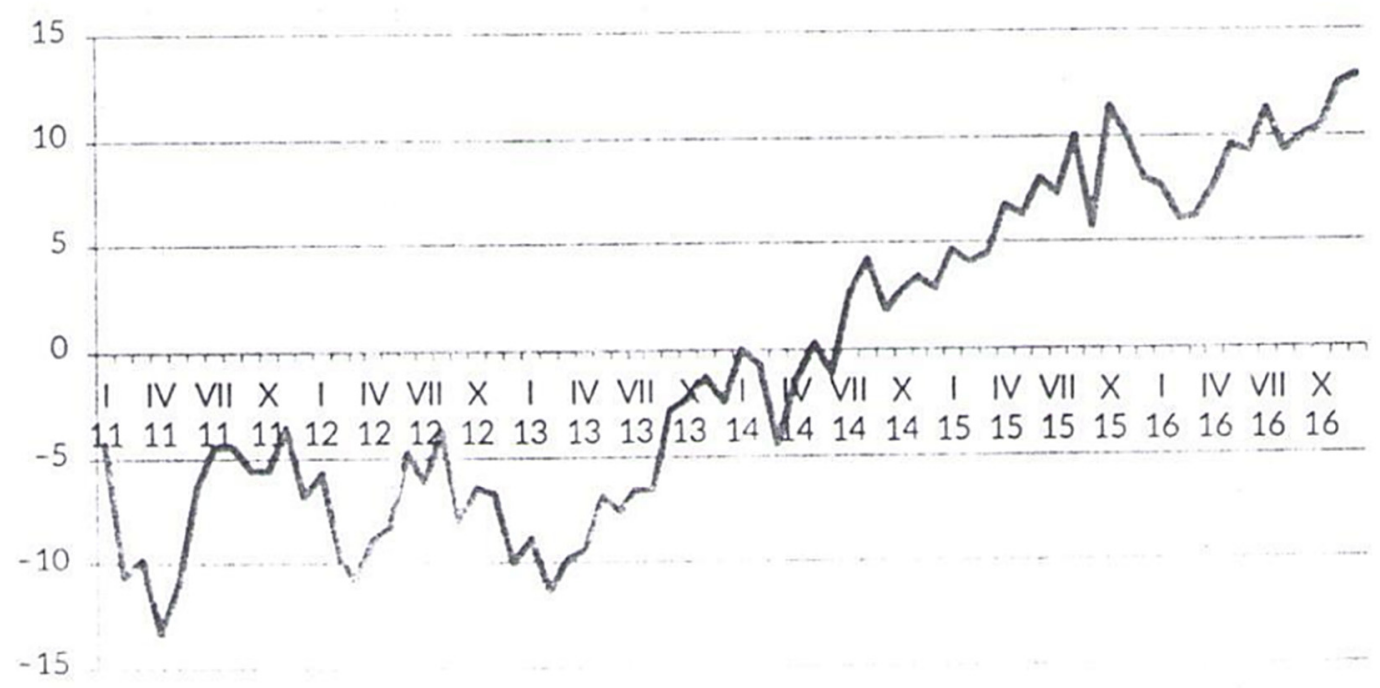

Figure 6. Financial condition of companies in the section "Transport and warehousing industry" in the period 2011 to 2016. (Source: Main office of Statistics (GUS), 2017b.).

Confirmation of fast growth, and in particular good economic performance of companies surveyed in the study, is a 2.5-fold increase of income from the sales of logistics, transport, and warehousing services in the period 2005 to 2016 (Figure 7). 


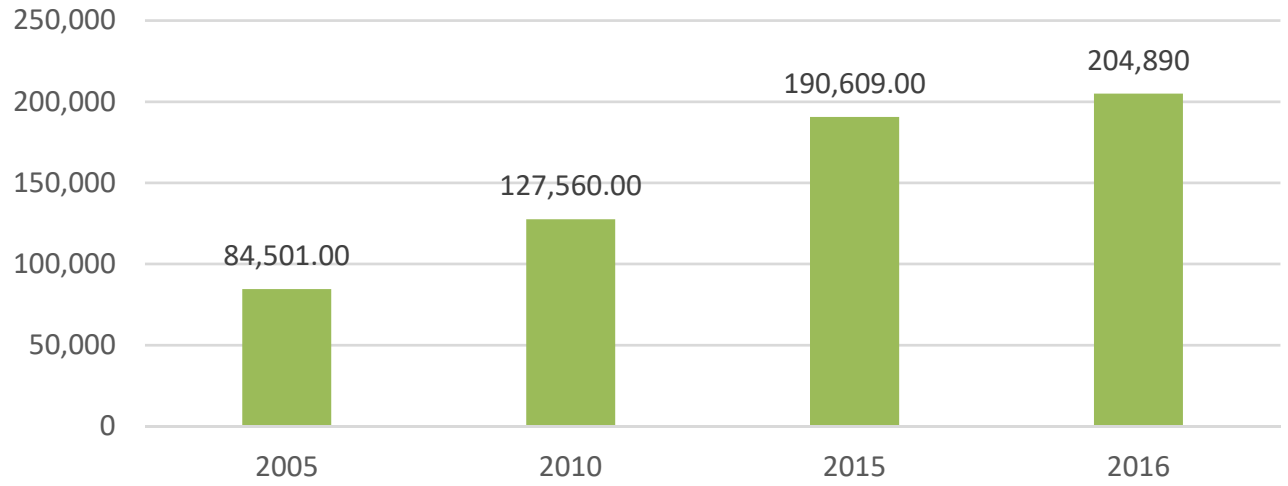

Figure 7. Sales of logistics, transport, and warehousing services in million Polish zlotys in the period 2005 to 2016 (Source: Main Office of Statistics, 2017b).

Judging solely by the performance of Polish providers of logistics services, as outlined above, the emergence of further forms of modern strategic alliances is very likely.

Strategic alliances are built on logistics competences, the last of the new logistics paradigms in international business analyzed in this article. This statement is clearly corroborated by the selection criteria that companies use to choose prospective partners in strategic alliances:

At least ten of the fourteen criteria presented in the diagram are clearly key logistics competences. Among these competences are the resources of the prospective ally, including its financial performance and financial propositions of collaboration (Figure 8). Other competences relate to the competitive position of the future ally, its ranking among logistics firms, or openness to innovation, and willingness to transfer skills and knowledge. Compared with the early 2000s, new competences have emerged, hitherto largely disregarded, such as geographical reach, testifying to the ally's ability to access supply and sales markets, and the partner's flexibility to accept changes in the terms of collaboration. Looking forward, the list of competences is likely to be supplemented with new, unique capabilities, whose quality will constitute added value to prospective allies.

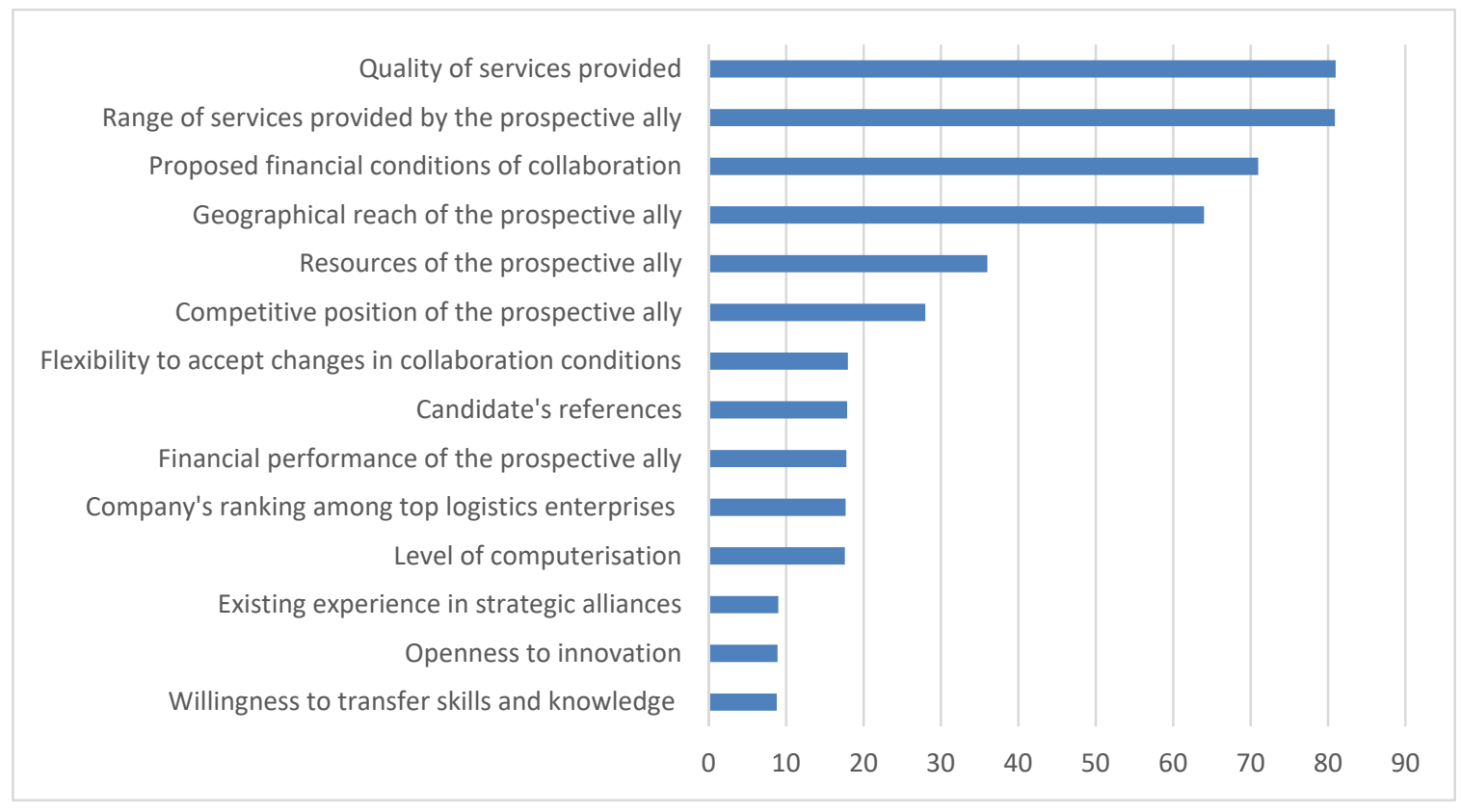

[\%]

Figure 8. Selection criteria for a partner in a strategic alliance. (Source: Own study). 
Achievements of Polish logistics in international business in the years 2000 to 2006 are commendable, and the prospects until 2020 also look positive. On this basis, with a high degree of probability we can envisage further positive trends in logistics development, and consequently a growing impact of logistics on company competitive advantage in international business [14]. The likely positive changes in modern logistics and in its role in the global economy will inevitably set the course for further research in the twenty-first century.

\section{Methods of Measuring Logistics Performance in International Business}

Within the broad scope of logistics competences are not only management skills ensuring a rational handling of logistics resources, but also the ability to measure logistics performance throughout international supply chains. It is worth mentioning that traditional competences, intrinsically connected with international business, include the ability to integrate with firms from different countries, the ability to formulate a corporate strategy and implement this strategy in line with defined financial goals, or the ability to satisfy customer preferences and needs. Such a bundle of logistics competences is required to achieve competitive advantage in the company's industry and throughout the supply chain. Advanced logistics competences are characterized by the existence of feedback between different types of capabilities. To measure performance of logistics operations, a multidimensional evaluation is needed of both internal and external logistics processes. The internal appraisal covers both key functional areas of a firm and logistics processes. The external assessment consists of monitoring relations and collaboration with business partners and other organizations in an international supply chain.

Logistics performance measurement is conducted with the use of both simple and complex metrics. The simple measures are often used to assess day-to-day logistics operations, and include such procedures as analysis of logistics costs, transport capacity, or inventory turnover. Complex measures are mainly used in profit forecasting, risk assessment, or appraisal of investment effectiveness in the planned payback period. An important measuring method, especially valuable in the appraisal of logistics operations, is the logit model. The value of this method lies in the fact that it answers the question whether the planned direct investments in logistics will end in success of failure. And thus, if the dependant variable $y$ assumes the following values:

$1=$ success - - the firm achieves greater profits

$0=$ failure - the firm does not achieve greater profits

then the logistic function has the following form:

$$
P(y=1 \mid X i=x i)=\frac{e^{a_{0}+a_{i} x_{i}}}{1+e^{a_{0}+a_{i} x_{i}}}
$$

The expression $P\left(y=1 \mid X_{i}=x_{\mathrm{i}}\right)$ denotes the probability of success (increased profits) at different values of the explaining variables, while $a_{0}$ and $a_{i}$ are the intercept and slope coefficients of the regression equation. Note that the logistic function assumes values in the range (0-1), and estimates the probability of event $z$.

The natural logarithm of the success chance is expressed as logit $(p)$, and when substituted in the logistic function yields the following logit model (Park 2013):

$$
\text { Logit }(p)=\ln \left(\frac{p}{1-p}\right)=a_{0}+a_{1} x_{1}
$$

where the expression $\left(\frac{p}{1-p}\right)$ denotes the ratio of the probability of success $p$ to the probability of failure $1-p$. Thus, we can establish how many times the probability of success is greater than the probability of failure (Figure 9). 


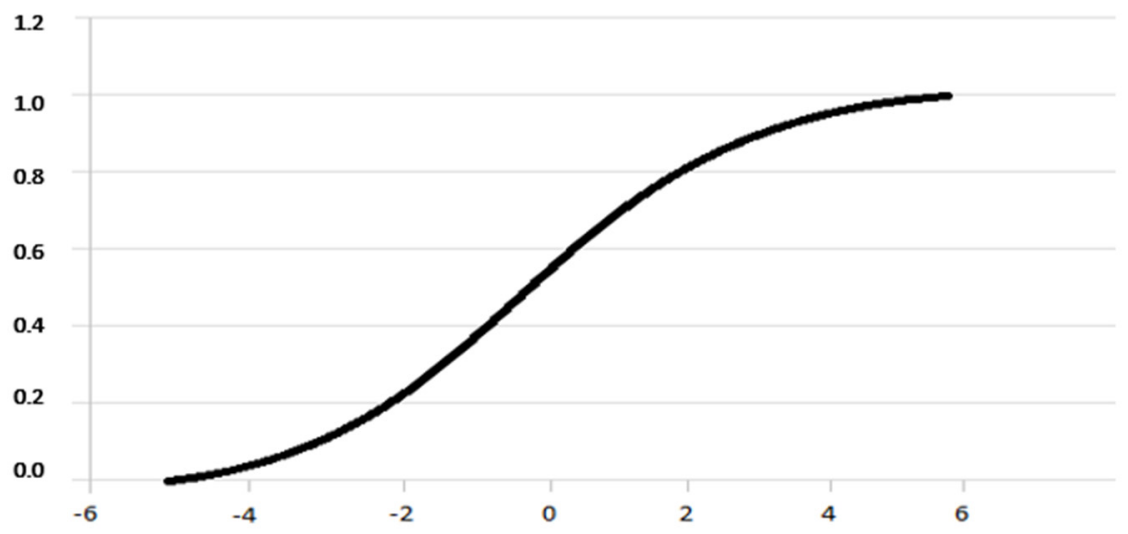

Figure 9. Logistic function curve (Source: own study).

The function is represented by the following graph:

A transformation of the logistic function led to a logit model, and consequently to a linear regression model, where $x$ is an explanatory variable (quantitative), and logit ( $p$ ), assuming positive real values, is the explained variable. The following example of computations uses the results of a survey of 146 firms investigating logistics infrastructure investments, such as warehousing facilities, transport fleets, and cargo processing facilities. It is assumed that the success criterion is satisfied if a firm reports a meaningful profit growth. For the purpose of logistic analysis, the success or failure indicators are binary variables, assuming the following values (Table 2):

0 -a success criterion is not satisfied

1 -a success criterion is satisfied

Table 2. An excerpt from the spreadsheet containing data used in the analysis.

\begin{tabular}{cccccc}
\hline Investment Outcome & $\begin{array}{c}\text { Reach } \\
\mathbf{x}_{\mathbf{1}}\end{array}$ & $\begin{array}{c}\text { Location } \\
\mathbf{x}_{\mathbf{2}}\end{array}$ & $\begin{array}{c}\text { Competition } \\
\mathbf{x}_{\mathbf{3}}\end{array}$ & $\begin{array}{c}\text { Market } \\
\mathbf{x}_{\mathbf{4}}\end{array}$ & $\begin{array}{c}\text { Outlay } \\
\mathbf{x}_{\mathbf{5}}\end{array}$ \\
\hline Success & 0 & 1 & 0 & 0 & 0 \\
Failure & 1 & 0 & 1 & 0 & 0 \\
Success & 0 & 0 & 1 & 1 & 0 \\
Success & 0 & 1 & 0 & 0 & 1 \\
Success & 0 & 1 & 0 & 0 & 0 \\
Failure & 0 & 1 & 1 & 1 & 0 \\
\hline
\end{tabular}

Source: Own study.

The explaining variables in the table's header are:

$\mathrm{x}_{1}$-the company's reach, a binary variable:

0 - the firm operates only in the local market

1 -the firm operates in international markets

$\mathrm{x}_{2}$-investment location, a binary variable:

0-investment in the existing location

1 -investment in a new location

$\mathrm{x}_{3}-$ market competition, a binary variable:

0-moderate to low competition

1-strong competition 
$\mathrm{x}_{4}$-market demand, a binary variable:

0-moderate demand

1 -strong demand

$\mathrm{x}_{5}$-planned investment outlay, a binary variable:

0-low

1-high

Computations were performed with the use of Statistica 10 PL software package.

The most insightful conclusions can be inferred from the "ratio of chances" row (Table 3). These are:

- The success chance of a company operating only in the local market, investing in existing locations, facing a low to moderate competition and enjoying a moderate demand is $13 \%$ lower compared with other firms, and subsequently the probability that it will generate profits is also lower,

- A firm operating in international markets has a 2.5 times better chance to be successful than a company operating merely in the local market,

- A firm investing in new locations, e.g., in a foreign country, has a $38 \%$ better chance of generating profits.

Table 3. Logit regression results.

\begin{tabular}{ccccccc}
\hline Parameter & $\begin{array}{c}\text { Constant } \\
\mathbf{B} \mathbf{0}\end{array}$ & $\begin{array}{c}\text { Reach } \\
\mathbf{x}_{\mathbf{1}}\end{array}$ & $\begin{array}{c}\text { Location } \\
\mathbf{x}_{\mathbf{2}}\end{array}$ & $\begin{array}{c}\text { Competition } \\
\mathbf{x}_{\mathbf{3}}\end{array}$ & $\begin{array}{c}\text { Market } \\
\mathbf{x}_{\mathbf{4}}\end{array}$ & $\begin{array}{c}\text { Outlay } \\
\mathbf{x}_{\mathbf{5}}\end{array}$ \\
\hline & -1.13 & 0.91 & 0.32 & 0.83 & 1.19 & 0.38 \\
Standard error & 0.19 & 0.17 & 0.12 & 0.11 & 0.21 & 0.20 \\
$\boldsymbol{t}$ & -0.06 & 5.52 & 2.62 & -7.09 & 5.55 & 0.19 \\
$\boldsymbol{p}$ level & 0.00 & 0.00 & 0.01 & 0.00 & 0.00 & 0.06 \\
$\mathbf{- 9 5 \%}$ CL & -1.50 & 0.59 & 0.08 & -1.06 & 0.77 & -0.02 \\
$\mathbf{+ 9 5 \%}$ CL & -0.77 & 1.23 & 0.57 & -0.60 & 1.61 & 0.78 \\
Chi-square & & & & & & \\
$\quad$ Walda & 36.69 & 30.47 & 6.87 & 50.28 & 30.76 & 2.99 \\
$\boldsymbol{p}$ level & 0.00 & 0.00 & 0.01 & 0.44 & 0.00 & 0.06 \\
Ratio of chances & 1.13 & 2.48 & 1.38 & 0.44 & 3.29 & 1.47 \\
$\mathbf{- 0 . 9 5 \% ~ C L ~}$ & 0.01 & 1.80 & 1.09 & 0.35 & 2.16 & 0.97 \\
$\mathbf{+ 0 . 9 5 \% ~ C L ~}$ & 1.29 & 3.43 & 1.77 & 0.55 & 5.00 & 2.02 \\
\hline
\end{tabular}

Source: Own calculations.

In logistics management the logit model is very useful, as it allows interpretation of many variables in different configurations. The outcomes of multiple computations provide a basis for the formulation of new strategic goals and stimulate the creation of new paradigms in the development of logistics.

Another measuring method, whose utility was recognized in the twenty-first century (Gołembska 2009), is the fuzzy logic model. It can be applied in a situation of a difference between risk and uncertainty of a business activity which is aimed at achieving a competitive advantage. Given that uncertainty is a special case of fuzziness, the membership set $M$ does not have to be a numerical set, since:

$$
M=P(y)
$$

where $P(y)$ is a family of all subsets $y^{n}$.

In strategic decision making, the fuzzy subsets method can be used independently of the logit method to select partners in a supply channel, where the selection criterion is investment in the expansion and modernization of logistics infrastructures, at home and abroad. In the case of four 
network members: $a, b, c$, and $d$, the membership set would be expressed by the following formula (Gołembska 2014):

$$
M=\frac{1}{2}\left(\frac{d}{1-c_{d}}+\frac{b}{b-a+1}\right)
$$

Next, we can use the tabular summary to infer which company, a member of a supply chain or network, does not invest sufficiently in logistics infrastructure. As a result, logistics partners gain an evidence base for eliminating such firms from collaboration.

As can be seen from the table (Table 4), firms $b$ and $d$ invest little or nothing in transport fleets or storage facilities, and thus should not be considered as prospective partners.

Table 4. A practical example of fuzzy subsets application.

\begin{tabular}{cc}
\hline Network Member & Assessment of Member Activities in a Logistics Network \\
\hline $\mathbf{a}$ & 0.750 \\
$\mathbf{b}$ & 0.000 \\
$\mathbf{c}$ & 0.219 \\
$\mathbf{d}$ & 0.000 \\
\hline \multicolumn{2}{c}{ Source: Own study. }
\end{tabular}

Examples of new, and hitherto rarely used methods of measuring logistics performance in international business require the application of state-of-the-art specialist software, capable of handling a large number of input data. The benefit of these new methods lies in the ability to predict future profits and business success in specific conditions of international business environment. Moreover, credibility and reliability of the computations require that multiple solution variants are considered, and that the results are comprehensive and comparable with results of similar studies in the industry or region.

\section{Conclusions}

The presentation of the findings from multiple studies, both methodological research and surveys of economic practice, constitutes a review of Polish logistics in the process of transformation, covering the period from 2000 to 2020, i.e., immediately before, and following Poland's accession to the EU. A good condition of the Polish logistics is confirmed by the country's 32nd place out of 150 nations in the World Bank's ranking based on Logistics Performance Index. In the same ranking Poland, as the only Central-Eastern European country, occupies the 17th place in Europe. The results of empirical studies justify the following conclusions:

- Investment in logistics infrastructure saw a fast growth, from $31.5 \%$ of total logistics outlay in the year 2000 , to $68.5 \%$ in 2016.

- The share of foreign capital in Polish logistics firms increased from $29.5 \%$ prior to Poland's accession to the EU to $78.5 \%$ in 2016.

- Foreign direct investments increased from $31.5 \%$ of total logistics outlay in the year 2000 to $84.2 \%$ in 2016.

- $\quad$ Export to EU countries grew from 40.8\% of total exports in the year 2000 to $81.4 \%$ in 2016.

- In the years 2000 to 2016 logistics management and organization of logistics in firms was thoroughly restructured, with the implementation of modern matrix organizational structure.

- The period 2000 to 2016 saw a steady increase in the number of logistics, transport, and shipping companies.

- During the period 2005 to 2016 corporate income from sales of logistics, transport, and shipping services increased two-and-a half fold.

Polish companies forecast that by 2020 the growth rate in logistics will exceed increases in logistics costs. The findings of studies involving over 400 Polish firms provide a valuable source of data both 
for managers and the government. In economic practice, examples of the use of the logit method and fuzzy subsets can serve as important and indispensable strategic management tools.

Funding: This research received no external funding.

Conflicts of Interest: The authors declare no conflict of interest.

\section{References}

1. Gorynia, M. On the interdisciplinary nature of international business. In Changes and Challenges in the Modern World Economy; Rynarzewski, T., Szymczak, M., Eds.; University of Economics and Business: Poznań, Poland, 2016; p. 119.

2. Matwiejczuk, R. Logistyczne potencjały w tworzeniu przewagi przedsiębiorstw. In Strategia i Logistyka w Warunkach KRYZYSU; Witkowski, W., ISkowrońska, A., Eds.; Wydaw. Uniwersytetu Ekonomicznego we Wrocławiu: Wrocław, Poland, 2015; pp. 363-375.

3. The Global Logistics Research Team at Michigan State University. World Class Logistics: The Challenge of Managing Continuous Change; Council of Logistics Management: Oak Brook, IL, USA, 1995.

4. Goldsby, T.J.; Stank, T.P. World Class Logistic Performance and Environmentally Responsible Logistic Practices. J. Bus. Logist. 2000, 21, 188.

5. David, P.; Steward, R. International Logisctics; Thomas: London, UK, 2008; p. 12.

6. Gołembska, E. Logistyka Międzynarodowa; PWN: Warszawa, Poland, 2014.

7. Giannakis, M.; Croom, S.; Slack, N. Supply chain paradigms. In Understanding Supply Chains; Oxford University Press: London, UK, 2004.

8. Gołembska, E.; Tunak, B. Alianse Logistyczne w Konkurencyjności Ustug Logistycznych; Wydawnictwo Wyższej Szkoły Bankowej: Poznań, Poland, 2018.

9. Gołembska, E. Logistyka międzynarodowa w europejskiej przestrzeni transportowej. In The Jubilee Book Dedicated to Professor Bogustaw Liberadzki and the Department of Transport at SGH on Its 50th Anniversary; SGH: Warszawa, Poland, 2018.

10. Pawlak, K.; Standar, A.; Kołodziejczak, M.; Kołodziejczak, W. Bezpośrednie Inwestycje Zagraniczne w Województwie Wielkopolskim —The Study Report; Uniwersytet Przyrodniczy w Poznaniu: Poznań, Poland, 2015.

11. Banaszyk, P.; Gołembska, E. Evolution of management of international supply networks and chains. In Changes and Challenges in the Modern World Economy; Rynarzewski, T., Szymczak, M., Eds.; Poznań University of Economics and Business: Poznań, Poland, 2016; pp. 235-236.

12. Shinohara, M. European and Japanese Logistics Paradigms: An Explorative and Comparative Study of the Dynamics of Logistics Management; Maruzen Planet: Tokyo, Japan, 2006.

13. Gołembska, E.; Banaszyk, P. Logistyka w Biznesie Międzynarodowym; WNT Publishers: Warszawa, Poland, 2015; p. 67.

14. Oláh, J.; Karmazin, G.; Máté, D.; Grabara, J.K.; Popp, J. The effect of acquisition moves on income, pre-tax profits and future strategy of logistics firms. J. Int. Stud. 2017, 10, 233-245. [CrossRef] [PubMed]

(C) 2019 by the author. Licensee MDPI, Basel, Switzerland. This article is an open access article distributed under the terms and conditions of the Creative Commons Attribution (CC BY) license (http://creativecommons.org/licenses/by/4.0/). 